\title{
Protest at Sea: the Arctic Sunrise Case and the clarification of Coastal States Rights
}

\author{
Protestos no Mar: o Caso Arctic Sunrise e a clarificação dos Direitos dos \\ Estados Costeiros
}

\author{
Paula de Castro Silveira ${ }^{12}$ \\ Grace Ladeira Garbaccio ${ }^{3}$ \\ ${ }^{1}$ Instituto Superior de Contabilidade e Administração de Lisboa, Lisboa, Portugal \\ ${ }^{2}$ Universidade Europeia de Lisboa, Lisboa, Portugal \\ ${ }^{3}$ Centro Universitário CESMAC, Farol, Maceió, AL, Brasil
}

\begin{abstract}
Protests at sea are more and more a tool used by non-governmental organizations to put pressure on the coastal States to give up exploration and exploitation of oil in the Arctic. However, regardless of their good intentions or the brightness of the banners flying, those protests could configure a severe threat to coastal States sights, as well as a real danger to the environment. Having that in mind, it is of extreme importance to understand how coastal States could lawfully act in the face of a protest of this kind. One of the most critically important cases concerning these types of events occurred in 2013 when Greenpeace activists engaged in a protest at the Russian Oil Installations, the Prirazlomnaya, located on Russia's continental shelf in the Pechora Sea, within Russia's exclusive economic zone (EEZ). This case resulted in relevant jurisprudence. In this article we will analyze the case and its importance to clarify the extent of Coastal State's jurisdiction regarding a protest at sea that could interfere with exploration and exploitation activities.
\end{abstract}

Keywords: Protest at Sea. Coastal States Rights. Exclusive Economic Zone. Prirazlomnaya.

Recebido em: 05/02/2019

Revisado em: 25/02/2019

Aprovado em: 11/03/2019
Resumo: Protestos no mar são cada vez mais uma ferramenta usada por organizações não governamentais para pressionar os Estados Costeiros a desistirem da pesquisa e da exploração de petróleo no Ártico. No entanto, apesar de suas boas intenções ou das brilhantes bandeiras que arvoram, esses protestos podem configurar uma grave ameaça aos direitos dos Estados Costeiros e são um perigo real para o meio ambiente. Tendo isso em mente, é de extrema importância entender como os Estados Costeiros poderiam, legitimamente, agir em face de um protesto desse tipo. Um dos casos críticos mais importantes com relação a esse tipo de eventos ocorreu em 2013, quando ativistas do Greenpeace protestaram contra as instalações russas de petróleo, o Prirazlomnaya, localizado na plataforma continental russa no mar de Pechora, na Zona Econômica Exclusiva (ZEE) da Rússia. Esse caso resultou em jurisprudência relevante. Neste artigo, será analisado esse caso e sua importância para esclarecer a extensão da jurisdição do Estado Costeiro sobre um protesto no mar que poderia interferir nas atividades de pesquisa e de exploração.

Palavras-chaves: Protesto no Mar. Direitos dos Estados Costeiros. Zona Econômica Exclusiva. Prirazlomnaya. 


\section{Introduction}

With the intensification of the economic exploitation of the oceans, maritime protests are, more and more, a tool used by non-governmental organizations (NGOs) to get community's attention and pressure for action on a range of issues, such as the over exploration of the Arctic; marine pollution; unrestrained oil exploitation in sensitive areas; among others.

"Save the Arctic" is the slogan of the campaign that Greenpeace International (hereinafter Greenpeace) and national/regional Greenpeace Organizations have been engaging in since 2010. During this campaign, on 18 September 2013, on board, the ship "Arctic Sunrise", flying the flag of the Kingdom of the Netherlands, Greenpeace activists engaged in a protest at the Russian Oil Installation, Prirazlomnaya. The objective of the protest was to draw attention to the potential environmental damages resulting from the exploration and exploitation of the Arctic.

This case resulted in two relevant court decisions, first by the International Tribunal for the Law of the Sea (ITLOS), subsequently by the Arbitral Tribunal, relating to the boarding, seizure, and detention of the Arctic Sunrise.

Although Russia refused to recognize the jurisdiction of either ITLOS, regarding provisional measures, or the Arbitral Tribunal, for the merits, this case gave to coastal States some clues on how to deal lawfully with a marine protest under the Law of the Sea.

Therefore, the purpose of this study is to analyse the jurisprudence of the case, in particular the arbitral award, and understand what kind of clarification it gives about the extent of coastal state's jurisdiction concerning protest at sea that could interfere with exploration and exploitation activities (MOSSOP, 2016, p. 61). 


\section{The Arctic Sunrise Case: the facts}

The dispute resulted from a set of events that took place from 16 to 19 September 2013.

On 16 September 2013, the Russian Federation Coast Guard vessel Ladoga warned the Arctic Sunrise crew by radio that a violation of the United Nations Convention on the Law of the Sea (UNCLOS) regarding the safety zone would not be tolerated.

The next day, when Arctic Sunrise moved into the direction of the installation, the Russian authorities advertised that the regulations should be followed and that it was not allowed to enter the area with a radius of three nautical miles around the facility as this meant a danger to the safety of navigation and the five-hundred-meter safety zone around the facility.

Regardless, on 18 September 2013, the Greenpeace activists engaged, on board the ship "Arctic Sunrise", in a protest at the Russian oil installation. They approached the installation in five rigid inflatable boats (usually called RHIBs) while the Arctic Sunrise remained at a threemile distance from the installation and just briefly came within the three nautical miles of it $^{1}$.

In response to the attempt of climbing the installation with ropes and a "safety pod" (a tube measuring 3 meters long by 2 meters wide and painted in bright colors), the Russian coast guard responded firing warning shots. In result, two of the activists (the Swiss and the Finnish national) were removed from the installation and taken aboard the Russian coastguard vessel (Request, p. 2 of Annex 2 of Annex 1). The remaining activists and RHIBs returned to the Arctic Sunrise (Request, p. 6 of Annex 2).

Following this incident started the diplomatic contacts between the Russian Federation and the Netherlands. In a verbal note, dated 18

\footnotetext{
${ }^{1}$ The "Arctic Sunrise" Case (Kingdom of Netherlands v. Russian Federation), Case No. 22, Request for prescription of provisional measures under Article 290, paragraph 5, of UNCLOS, of 21 October 2013 (hereinafter Request), ITLOS, available at http://www. itlos.org/fileadmin/itlos/documents/cases/case_no.22/
} 
September 2013, the Russian Federation informed the Netherlands that it had decided "to seize The Arctic Sunrise" arguing that those actions "exposed the Arctic region to the threat of an ecological disaster with unimaginable consequences" (Request, p. 3 of Annex 2 of Annex 1; The request, p. 3 of Annex 2 of Annex 1).

On 19 September, after almost a day and a half on board the Russian Coast Guard vessel, the two activists returned to the Arctic Sunrise (Request, p. 8 of Annex 2). Subsequently, the Russian authorities boarded the intruding vessel, arrested the crew and detained the ship.

In reply, the Netherlands argued that the Russian Federation's actions "breached its obligations owed to the Kingdom of the Netherlands regarding the freedom of navigation and its right to exercise jurisdiction over the Arctic Sunrise" (Request, p. 4). Subsequently, the Netherlands instituted arbitral proceedings against the Russian Federation under Annex VII to the UNCLOS and, on 21 October 2013, submitted a Request for provisional measures to ITLOS (Request, p. 4).

On 22 November 2013, ITLOS announced its ruling in the Arctic Sunrise Case (Kingdom of the Netherlands v. Russia Federation) ordering the release of the crew and the ship upon the posting of a bond by the Netherlands. Concomitantly, the Russian Parliament granted amnesty from criminal charges to all persons on board the vessel and the crew, following which the ship was released.

The Arbitral Tribunal made its award on 14 August 2015, declaring that the boarding and seizure of the Arctic Sunrise by the Russian Federation and the arrest of the Arctic Sunrise and its crew was illegal, and ordering the Russian Federation to compensate the Netherlands for the damage caused to the Arctic Sunrise and its crew.

\section{The Qualification of Actions of Protest at Sea: Piracy? Terrorism?}

The Russian Federation made several assertions as to the legal basis for the arrest of the vessel and its crew (MOSSOP, 2016, p. 63). First, 
they qualified Greenpeace acts as piracy (NOTO, 2016, p. 37), under article 101 of UNCLOS. The qualification of the acts of protest at sea as piracy would present a valid solution to the issue of lack of jurisdiction to approach the Arctic Sunrise without the authorization of the Flag State. After all, under the terms of article 105 and article 110, paragraph 1, a) of UNCLOS if the Coastal State has reasonable grounds to suspect piracy, it has the right of access and seize the ship. However, it is questionable whether an act of piracy could be committed against an offshore oil facility.

Piracy is defined as any illegal act of violence or detention, or any act of depredation committed for private ends by the crew or passengers of a private Ship and directed against: (i) a ship on the high seas (named as the "two-vessel requirement"); or (ii) a vessel not subject to the jurisdiction of any State.

Several elements could be common to both acts of protest at sea and piracy, the article 101 of UNCLOS is broad enough to encompass the protest situation. Several national courts (MENEFEE, 1993, p. 7 ss.) have considered non-violent protest acts as acts of piracy, namely "Castle John and Nederland's Stichting Sirius versus NV Mabeco and NV Parfin", the Belgian Court of Cassation qualified as piracy the acts of protest undertaken by Greenpeace activists against two Belgian vessels, the NV Mabeco and the NV Parfin, which had discharged toxic substances on the high seas (NOTO, 2016, p. 41).

In this case, however, to qualify the situation as piracy it is necessary to qualify the oil installation as a "Ship," which is not a peaceful assertion, and, on the other hand, rationalize the environmental protection as a "private" end (HONNIBALL, 2015, p. 5 ss.), which is quite difficult due to the public nature of the good in questions - the "environment."

As such, the Arbitral Tribunal considered that The Prirazlomnaya is not a ship. It is an offshore ice-resistant fixed platform (NETHERLANDS v RUSSIA (Merits), p. 57, paragraph 238). Therefore, the boarding, seizure, and detention of the Arctic Sunrise cannot be justified as an exercise of the right of visit to the Arctic Sunrise on suspicion of piracy 
as provided under Article 110 of the Convention (NETHERLANDS v RUSSIA (Merits), p. 57, paragraph 241).

Secondly, although the Arctic 30 were never charged with terrorism offenses, the Russian authorities accused the crew of the Arctic Sunrise of maritime terrorism, as provided by the Protocol for the Suppression of Unlawful Acts against the Safety of the Fixed Platform located on the Continental Shelf of 1988 (hereinafter SUA Protocol 1988) and the Convention for the Suppression of Unlawful Acts against the Safety of Maritime Navigation of 1988 (hereinafter SUA 1988) (NETHERLANDS v RUSSIA (Merits), p. 81, paragraph 32).

The 1988 SUA Protocol states that the provisions of SUA 1988 apply mutatis mutandis to "fixed platforms" in the sense of "[...] artificial island, facility or structure permanently attached to the seabed for exploitation of resources or for other economic purposes" (Article 1, of SUA Protocol 1988).

The facts described above could fall under the infringement referred to in Article 2 (d) of the 1988 SUA Protocol, which provides: "to place or cause to be placed on a fixed platform by any means a device or substance which is capable of destroying it or endangering its security." This provision is broad enough to cover the vicissitudes of the case and guarantee coastal State jurisdiction.

It also provides that each State party shall take such measures as may be necessary to establish its jurisdiction over the crimes listed. The State, therefore, has jurisdiction in respect of such offenses when they are committed: (i) against or on board a fixed facility while located on the continental shelf of that State; (ii) by a national of that State; (iii) by a stateless person habitually resident in that State; (iv) if, during his practice, a national of that State is abducted, threatened, injured or killed; or $(\mathrm{v})$ is committed in an attempt to compel that State to practice or cease to exercise any act (Article 3 (1), of SUA Protocol 1988).

However, the 1988 SUA Protocol nowhere refers to what it considers to be these "measures" to establish its jurisdiction as mentioned above. The Convention and the Protocol were amended in 2005 by 
broadening the range of offenses and balancing the relationship between the Coastal States and the Flag State concerning such crimes, as well as by establishing formal procedural measures to be followed if such offenses are committed. However, one of the essential features of SUA 2005 - Article 8bis - which stipulates the procedure for obtaining the consent of the Flag State to address a ship suspected of involvement in one of these crimes has not been incorporated into the Protocol 2005 on Fixed Platforms (HAREL, 2012, p. 171).

Some authors consider this to be "regrettable," stating that the inclusion of this provision in the 2005 SUA Protocol would have promoted, to some extent, efforts to protect offshore oil installations. In practice, if these provisions were applied, mutatis mutandis, to the 2005 SUA Protocol, it would encounter difficulties in coexisting with the "exclusive competence" provision of the Coastal States in the premises, as well as in the security zones established under UNCLOS. After all, the Coastal State is already authorized to address and even detain individuals who endanger a fixed installation, whether it is in the facility itself or within the safety zone surrounding it.

Regarding the Arctic Sunrise case, some essential facts should be emphasized regarding the implementation of the SUA Protocol. First, the Kingdom of the Netherlands and the Russian Federation are both Party to the 1988 SUA Protocol; however, only the Kingdom of the Netherlands is a party to the 2005 SUA Protocol. Therefore, the 1988 version would prevail. However, this is not enough on its own, because this instrument doesn't have specific provisions regarding enforcement powers. So, in cases of terrorism, we have still to analyse the situation under UNCLOS provisions regarding enforcement powers. It may be due to this fact that the Russian Federation did not charge the Arctic Sunrise crew for terrorism.

\section{Law Enforcement Powers: right of hot pursuit}

Therefore, the boarding, seizure, and detention of a vessel in the EEZ without the consent of the flag State, and without suspicion of 
piracy as provided under Article 110 of UNCLO, just find a basis under international law if the requirements of hot pursuit are satisfied.

The hot pursuit (SILVEIRA, 2001) already part of customary law, is codified in article 111 of UNCLOS. Article 111 (2) gives the right of hot pursuit mutatis mutandis to violations of the laws of the territorial state in the EEZ, or the continental shelf, including safety zones around continental shelf installations (CRAWFORD, 2012, p. 310; POULANTZAS, 2002, p. 167 ss.).

In short, the right of hot pursuit is the right of a coastal state to pursue outside of territorial waters, and take enforcement action against, a foreign ship that has violated the laws and regulations of that State. It serves to prevent foreign vessels that have broken the rules and regulations of a coastal State from evading responsibility by fleeing to the high seas (NETHERLANDS v RUSSIA (Merits), p. 58, paragraph 245).

The Arctic Sunrise "briefly enters" the safety zone (REQUEST, p. 4 of Annex 2). Therefore, it could be argued that the ship is not subject to the regime of hot pursuit. However, Article 111 (4) adopts the doctrine of "the mother vessel," a ramification of the doctrine of "the constructive presence," which allows the right of hot pursuit to a mother ship for the activities of its boats or other crafts as they work as a team. Hence, the Arctic Sunrise and the inflatable boats, which were launched from it, acted as a team and therefore the ship Arctic Sunrise is equally responsible for the violations committed.

As stated by ITLOS in M/V "SAIGA" (n. 2), the conditions set out in Article 111 for the exercise of the right of hot pursuit are "cumulative. Each of them has to be satisfied for the pursuit to be legitimate under the Convention" ${ }^{2}$.

The first requisite for the legitimate exercise of the right of hot pursuit set out in Article 111(1) of UNCLOS, is that the competent authorities of the coastal State must have good reason to believe that the

\footnotetext{
${ }^{2} \mathrm{M} / \mathrm{V}$ Saiga (Saint Vincent and The Grenadines v Guinea), Case n. 2, Judgment, ITLOS, available in http://www.itlos.org/index.php?id=59, last viewed on 8 May 2014, paragraph 146.
} 
vessel being pursued has violated the laws or regulations of that State. In this case are relevant the applicable laws and regulations applicable in the safety zone and installation in the EEZ (NETHERLANDS v RUSSIA (Merits), p. 60, paragraph 247).

During the events, Russia unequivocally stated the view that a 500 -meter zone prohibited to navigation existed around the installation. Consequently, the Tribunal proceeded on the assumption that a safety zone had been validly established around the platform and that navigation was prohibited in that zone.

Therefore, the Russian Federation would have had good reason to believe that the RHIBs violated that prohibition in the morning of 18 September 2013. This violation would have constituted enough reason to commence pursuit under Article 111 of UNCLOS (NETHERLANDS v RUSSIA (Merits), p. 61, paragraph 251).

Furthermore, hot pursuit cannot be initiated merely after a warning from the installation, it must commence with a visual or auditory signal to stop from a pursuing vessel or an aircraft (Article 111 (4) of UNCLOS). It cannot come from the installation, as only ships and aircraft have such authorization under Article 111 (5), and even from that category, they must be identified as being on government service. Also, the practicalities of the requirement of a visual or an auditory signal mean the pursuer must be physically close to the installation, which of itself would probably deter the incursion in the first place. Secondly, the visual or auditory signal must be made while the offending vessel is physically in the safety zone. Given the zone's small size, and the expectation that a fleeing ship will be in the safety zone, at best the opportunity to commence hot pursuit is limited (Article 111 (4) of UNCLOS).

The Tribunal considered that any order to stop given to the RHIBS of the Arctic Sunrise during their scuffle with the RHIBs of the Ladoga within the 500-meter safety zone of the installation would not have been valid under UNCLOS, as the Convention requires that stop orders are given to the main ship which is to be pursued. However, the evidence shows that orders to stop were delivered directly to the Arctic Sunrise by VHF radio (NETHERLANDS v RUSSIA (Merits), p. 62, 
paragraphs 255-256). Regarding this fact, the Tribunal went further and defended a modern interpretation of the Convention, stating that the parameters of the right of hot pursuit must be interpreted in the light of their object and purpose, having regard to the modern use of technology (NETHERLANDS v RUSSIA (Merits), p. 62-63, paragraph 259).

Having in mind that the principal object of the rule regarding signals contained in Article 111(4) is to ensure that the pursued ship is made aware of the pursuit, the Tribunal's understanding was that VHF messages presently constitute the standard means of communication between ships at sea and can fulfill the function of informing the pursued ship. Therefore, in the present case, it is unquestionable that the Arctic Sunrise was aware of the pursuit, as at least some of the radio messages to stop were received and acknowledged. For these reasons, the Tribunal decided that the auditory signal was valid, which means that the pursuit should commence with the transmission of the first radio message to stop if, on that moment, at least one of the RHIBs was still within the 500-meter zone around the installation (NETHERLANDS v RUSSIA (Merits), p. 62, paragraph 260-261).

Having in consideration the evidence before it, the Tribunal concluded that the first stop order was probably given (even if only a minute or two) after the last of the RHIBs exited the 500-metro zone around the installations.

The Tribunal, however, notes that the formulation of Article 111(4), suggests that the location of the foreign ship at the time of the first stop order should not be evaluated with the full benefit of hindsight, but instead looked at from the perspective of the pursuing ship (NETHERLANDS v RUSSIA (Merits), p. 65, paragraphs 266-267). Therefore, given the closeness in time of the first stop order and the departure of the RHIBs from the safety zone, this requirement should be satisfied.

Besides the practicalities, to qualify the pursuit as "hot," the quest should not be interrupted (Article 111 (1) of UNCLOS). Therefore, the lawful performance of the right of hot pursuit requires the immediate commencement of the hunt and its uninterrupted continuation upon the high seas. 
If an analysis of the case is carried out on the literal meaning, it will appear that the right of hot pursuit can be initiated against a ship that makes an unauthorized entry into a safety zone around an installation, even though that ship may only be briefly in such an area, as in the case of the Arctic Sunrise. It may also continue to be pursued for as long as 36 hours, based on hot pursuit. It could be argued that the Russian authorities had authority to take enforcement measures against the Arctic Sunrise as the mother ship, and, consequently, that the boarding, arrest of the crew and detention of the vessel were valid under international law.

In the light of the factual account of events, during the three hours following the first stop order, the Russian Authorities conduct consisted with the notion of hot pursuit. However, after the initial flurry of orders, threats, and warning shots, from approximately 9:30 on 18 September 2013 the Russian Authorities behaviors changed, unloading its gun mounts and ceasing issuing orders to the Arctic Sunrise.

In spite of the Russian authorities decision to seize the Arctic Sunrise, as expressed in the note verbal of the same date, and the Arctic Sunrise remaining within the mediations of the three-nautical miles of the installation, the persecution was not continued. Nothing in the description of the events shows a continuing pursuit of the Arctic Sunrise, as should have happened, missing the element of "hotness" of the pursuit and therefore falling out the scope of the provision of hot pursuit.

In the absence of hot pursuit, as described in UNCLOS, what can a coastal State do when faced with an attack on the installation, safety zone or to the surrounding environment?

\section{Another Possible Means of Defense of Coastal States Rights Facing a Protest at Sea}

One of the most important contributes of this case for the clarification of coastal States rights to protect their rights in the safety zone, installation and EEZ, is given by the broad analysis that was made 
in relation to other forms of defence of coastal States facing a protest at sea in that zones.

First, the award of the Arbitral Tribunal recognized that acts of peaceful protest at sea may result in possible disruption of the freedom of navigation and expressed the view that this should be tolerated by the coastal State so long as they do not interfere with the exercise of its sovereign rights (NETHERLANDS v RUSSIA (Merits), p. 82, paragraph 328).

The Tribunal gave specific indications to identify which acts of protest could be reasonably considered to constitute an interference with a coastal State's sovereign rights, particularly in the context of this case. Therefore, it would be reasonable for a coastal State to act to prevent: i) violations of its laws adopted in conformity with the Convention; ii) dangerous situations that can result in injuries to persons and damage to equipment and installations; iii) negative environmental consequences; and iv) delay or interruption in essential operations (NETHERLANDS v RUSSIA (Merits), p. 82, paragraph 327).

Given the "constructive presence" adopted by Article 111 (4) UNCLOS, the five RHIBs launched from the Arctic Sunrise that approached the installation gave rise to a breach of the safety zone around the platform. That provided a basis to allow the adoption of preventive measures, by the Russia Federation against the intruder ship, to avoid delay or interruption in essential operations of the installation (NOTO, 2016, p. 55) $)^{3}$. However, at the time it was boarded and seized, the Arctic Sunrise was no longer engaged in actions that could potentially interfere with the exercise by Russia of its sovereign rights as a coastal State (NETHERLANDS v RUSSIA (Merits), p. 82, paragraph 327).

The Tribunal noted that Article 78 of UNCLOS provides that the exercise of the rights of a coastal State over the continental shelf "must not infringe or result in any unjustifiable interference with navigation and other rights and freedoms of the other States as provided in the

\footnotetext{
${ }^{3}$ Dissenting Opinion of Judge Golitsyn, paragraph 35, p. 10, available in http://www. itlos.org/fileadmin/itlos/documents/cases/case_no.22/Order/C22_Ord_22.11.2013_diss. op.Golitsyn_orig_Eng.pdf.
} 
Convention." Therefore, the boarding and seizing of the Arctic Sunrise would have infringed and unlawfully interfered with the navigation and other rights and freedoms of the Netherlands (NETHERLANDS $\mathrm{v}$ RUSSIA (Merits), p. 83, paragraph 331).

\section{Conclusion}

In addition to the media relevance that the case assumed during the time that the Russian Federation detained the Arctic Sunrise Ship and its crew, the legal issue raised by this case is an important precedent to point out.

The Tribunal reaffirms that, according to UNCLOS, international law provides coastal States with "sovereign rights" for exploration, conservation, and management of natural resources, so it would be necessary to analyse, case by case, if the acts of protest at sea pose a severe threat to EEZ's rights of coastal State.

However, although Russia has the right to protect the facility and the surrounding marine environment, the end does not justify the means. Although they were able to respond legally to the attack, they did not follow the procedures required by the law of the sea for the persecution and, consequently, it cannot be described as "hot." Therefore, the fact of being aboard the Vessel without the consent of the Kingdom of the Netherlands, Flag State, constituted a violation of international law, incurring potential responsibility on the part of Russia. The situation would have been different had the procedures described in the law of the sea been followed to protect the offshore installation and, consequently, the rights over the EEZ. Greenpeace was thus allowed to present itself as the innocent victim of a violating State although, in fact, the Russian Federation had good reason to act against the Arctic Sunrise Ship. To make this a lawful action, the Russian Federation would only need to have taken advantage of the various opportunities it had to do according to UNCLOS in compliance with all the requirements of Article 111. 


\section{References}

HAREL, Assaf. Preventing Terrorism Attacks on Offshore Platforms: Do States Have Sufficient Legal Tools? Harvard National Security Journal, [S.l.], v. 4, p. 131-184, 2012.

HONNIBALL, Arron N. The "Private Ends" of International Piracy: The Necessity of Legal Clarity in Relation to Violent Political Activists, International Crimes Database, Brief 13, October, 2015.

KASHUBSK, Mikhail. Protecting Offshore Oil and Gas Installations: Security Threats and Countervailing Measures, in the Journal of Energy Security, on 11 December 2013.

MENEFEE, Samuel Pyeatt. The Case of the Casteh Hohn, or Greenbeard the Pirate? Environmentalism, Piracy and the Development of International Law. California Western International Law Journal, California, v. 24, Number 1, Fall 1993.

MOSSOP, Joanna. Protests Against Oil Exploration at Sea: Lessons from the Arctic Sunrise Arbitration. Victoria University of Wellington Legal Research Papers, Paper n. 10/2018, Volume 8, Issue n. 2, 2018.

NOTO, Maria Chiara. The Arctic Sunrise Arbitration and Acts of Protest at Sea. Maritime Safety and Security Law Journal, [S.l.], Issue 2, p. 37, 2016.

POULANTZAS, Nicholas M. The Right of Hot Pursuit in International Law. Second Edition, The Hague: Martinus Nijhoff Publishers, 2002.p. 167 ss.

SILVEIRA, João Tiago, A Hot Pursuit Nos Mares. Revista Jurídica da AAFDL, n. 24, p. 85-136, April, 2001.

Grace Ladeira Garbaccio é Doutora e mestre em Direito pela Universidade de Limoges, França - reconhecida pela Universidade Federal de Santa Catarina (UFSC). Professora convidada da Université Laval, Québec, Canadá. Professora 
do curso de Direito do CESMAC. Professora do curso de pós-graduação lato sensu na FIA, IDP, ESPM e FMU.

E-mail: glgarbaccio@hotmail.com ou grace.garbaccio@rcarneiroadvogados. com.br

Endereço profissional: Rua Elvira Ferraz, n. 250, cj 1.014 e 1.015 - Complexo Faria Lima. São Paulo, SP. CEP: 04.552-040.

Paula de Castro Silveira é Doutora pela Universidade de Lisboa, L.L.M (IMOIMLI), L.L.M pela Universidade de Lisboa. Professora no Instituto Superior de Contabilidade e Administração de Lisboa (ISCAL) e da Universidade Europeia. Pesquisadora na THD da Universidade de Lisboa, Centro de Investigação da Faculdade de Direito da Universidade de Lisboa, Portugal; CEDIS, Centro de I\&D sobre Direito e Sociedade, Faculdade de Direito, Universidade Nova de Lisboa, e CEDMAR-USP, Centro de Estudos em Direito do Mar "Vicente Marota Rangel" da Faculdade de Direito da Universidade de São Paulo.

E-mail: paulacastrosilveira@gmail.com ou pcs@mgra.pt

Endereço profissional: Avenida Praia da Vitória, n. 48, 3dto, Lisboa, Portugal. CEP 1050-148. 